\title{
BİTKİ TOHUM MUSİLAJLARI VE GIDALARDA KULLANIMI
}

\author{
Umay Sevgi Vardar ${ }^{1}$, Yılmaz Özcan ${ }^{2 *}$, Duygu Özmen ${ }^{1}$, Ömer Said Toker ${ }^{1}$ \\ ${ }^{1}$ Yıldız Teknik Üniversitesi, Kimya-Metalurji Fakültesi, Gıda Mühendisliği Bölümü, İstanbul, Türkiye \\ ${ }^{2}$ Kırklareli Üniversitesi, Mühendislik Fakültesi, Gıda Mühendisliği Bölümü, Kırklareli, Türkiye
}

Geliş / Received: 05.05.2020; Kabul / Accepted: 24.12.2020; Online bask1 / Published online: 28.01.2021

Vardar, U.S., Özcan, Y., Özmen, D., Toker, O.S. (2021). Bitki tohum musilajları ve gıdalarda kullanımı. GID $A$ (2021) 46(2) 269-278 doi: 10.15237/gida. GD20073.

Vardar, U.S., Özcan, Y., Özmen, D., Toker, O.S. (2021). Plant seed mucilages and its use in foods. GIDA (2021) 46(2) 269-278 doi: 10.15237/gida. GD20073.

\section{ÖZ}

Hidrokolloidler, jelleşme, kalınlaştrrma, emülsiyon ve köpükleri stabilize etme gibi teknolojik özelliklerinden dolayı gıda endüstrisinde yaygın olarak kullanılmaktadır. Son yıllarda tüketicilerin doğal katkılı gıdalara olan ilgisi araştırıcların ticari hidrokolloidlerin yerine bitki tohum musilajlannna olan ilgilerini artırmıştr. Bitki tohum musilajları teknolojik özelliklerinin yanı sıra diyet lifi olma özelliğinden dolayı eklendikleri ürüne fonksiyonel özellik kazandırmaktadır. Musilajların fonksiyonel özellikleri yapılarındaki şekerden dolayı sıcaklık gibi ektraksiyon koşullarından etkilenmekte olup enzim uygulaması, ultrasonik ve mikrodalga destekli yöntemler de musilaj ekstraksiyonun da kullanılabilmektedir. Bu derlemede, musilajların farklı kaynaklardan farklı yöntemler ile elde edilmesi ve firınclık, süt ve et ürünlerinde kullanımı ile ilgili yapılan çalışmalar özetlenmiştir.

Anahtar Kelimeler: Musilaj, hidrokolloid, gam, eksktraksiyon

\section{PLANT SEED MUCILAGES AND ITS USE IN FOODS}

\begin{abstract}
Hydrocolloids are widely used in the food industry due to their technological properties such as gelling, thickening, emulsion and foam stabilization. In recent years, consumers' interest in minimally processed foods has increased researchers' interest in plant seed mucilage rather than commercial hydrocolloids. Plant seed musilages add functional properties to the product they are added to due to their technological properties as well as being dietary fiber. Functional properties of mucilages are affected by extraction conditions such as temperature due to the presence of sugar in their structure, and enzyme treatment, ultrasonic and microwave assisted methods can also be used in musilage extraction. In this review, studies on extraction mucilages from different sources and using them in bakery, dairy and meat products are summarized.
\end{abstract}

Keywords: Mucilage, hydrocolloid, gum, extraction

\footnotetext{
${ }^{*}$ Yazışmalardan sorumlu yazar / Corresponding author

11):yilmaz.ozcan@klu.edu.tr, (1): (+90) 2882140514

盀: (+90) 2882140516

Umay Sevgi Vardar; ORCID no: 0000-0002-4900-8009

Yılmaz Özcan; ORCID no: 0000-0002-6763-3158

Duygu Özmen; ORCID no: 0000-0002-1052-3599

Ömer Said Toker; ORCID no: 0000-0002-7304-2071
} 


\section{GİRİ̧̧}

Hidrokolloidler yapilarındaki hidroksil gruplarından dolayı suda çözünebilen biyopolimer gruplarıdır. Stabilize ve emülsifiye etme, jelleşme, kalınlaştırma ve retrogradasyonu önleme gibi işlemlerde yer alarak gıdaların fonksiyonel ve reolojik özelliklerinin iyileştirilmesinde kullanılmaktadırlar. Bu yüzden gıda prosesleri için önemli bir katk1 maddesi olup dondurma, salata sosu ve jöleli tatlılar gibi gida ürünlerinde yer almaktadirlar (BeMiller vd. 2011; Yuan Hung vd. 2019; Saha ve Bhattacharya, 2010).

Emülsifiyerler, emülsiyon bazlı ürünlerin önemli bir bileșenidir. Gıda endüstrisinde sukroz ve sorbitan esterleri gibi sentetik emülsifiye edici ajanlar yaygın olarak kullanılmaktadır. Bununla beraber sentetik emülsifiyerlerin birçok alerijk ve otoimmün hastalıkların görülme sıklığını arttırdığ1 belirtilmiştir (McClements vd. 2017). Bu yüzden spesifik fonksiyonel özellikler (yapısal, fizikokimyasal) gösterebilen yeni g1da hidrokolloid kaynaklarının araştırılması son zamanlarda artış göstermiştir. Bu amaçla yeni hidrokolloid kaynağı olarak müsilajlar üzerinde yapilan araşturmalar günden güne yoğunlaşmaktadır (Da Silva vd. 2019). Tohum musilajlarının kolloidal özelliklerinden dolayı gıda ve diğer endüstrilerde emülsifiye edici ve kalınlaştıııcı ajan olarak kullanılabileceği belirtilmiştir. Ayrıca, teknolojik özelliklerinin yanısıra tohumların müsilajinöz bileşenlerinin diyet lifi fonksiyonları dolayisiyla da insan sağllğıı fayda sağlayacağı vurgulanmıştır (Pereira vd. 2019).

\section{Tohum Musilajlarının Özellikleri}

Bitki tohumlarnndan elde edilen polisakkaritler, yapısal ve tekstürel özellikler kazandırma, emilsülfiye etme ve kıvam arttırma gibi kendilerine özgü teknolojik faydaları ve diyet liflerinin doğal kaynağı olmaları gibi besinsel yararları ile gida sanayinde kullanılan önemli hidrokolloidlerden biridir. Bitki tohumu polisakkaritleri genel olarak galaktomannanlar gibi nişasta olmayan endosperm bileşenleri, tohum tabakası müsilaj bileşenleri (keten, çiya, sarı hardal, pisilyum) ve endosperm hücre duvarı bileșeni (soya fasulyesi hemiselülozu) olmak üzere üç grupta sinıflandırilırlar (Soukulas 2018). Müsilaj polisakkaritleri, bitkilerde tohum hidrasyonunun korunmasinda ve kurak koşullarda hayatta kalmasında görev alan bitki hidrokolloidleridir (Yu vd. 2017).

Musilajlar genellikle gamlar ile karıştırlmaktadır ancak bu iki kavram birbirinden farklıdır. Gamlar, genellikle bitkilerin bir yaralanma ya da hücre duvarının zedelenmesi ile ürettikleri bileşenler olarak düşünülürken müsilajlar metabolizmanın olağan olarak ürettiği ürünlerdir. Gamlar patolojik ürünler olup suda çözünürken müsilajlar fizyolojik ürünler olup suda çözünen sümüksü kitleler oluşturur (Jani vd. 2009). Akasya, tarakant ve guar gam gam çeşitlerinden bazılarıdır. Müsilajlar ise bitkinin yaprak (sinameki), tohum zarı (keten tohumu, psilyum), kök (hatmi), kabuk (karaağaç) ve orta lamel (aloe) gibi birçok farklı kisımlarında bulunur (Jani vd. 2009).

Gamlar ve musilajlar bazı benzer özelliklere de sahiptir. Bitkisel hidrokolloid olmalar1 ve yar1 saydam amorf özellik göstermeleri ortak özellikleri arasındadır. Bununla birlikte her ikisi de bir monosakkaritin veya monosakkarit karışımının polimerleri olup birçoğu üronik asitlerle bağ yapmış formdadır (Jani vd. 2009). Galaktoz, galakturonik asit kalıntıları içermesinin yanı sıra çoğunluk olarak da arabinoz ve ksiloz içermektedirler. Kimyasal yapılanı incelendiğinde 1,4 ve 1,3 bağlariyla bağlı arabinoksilan polimerleri olduğu görülmektedir (Abdurrahmanoğlu, 2017). Benzer bileşenlere sahip olan gamlar ve musilajlar hidroliz sonucu şeker ve üronik asit karışımı oluştururlar (Jani vd 2009). Düz zincirli polisakkaritler aynı molekül ağırlı̆̆ındaki dallı bileşenler ile kıyaslandığında daha fazla yer kaplar ve viskoz yapı oluştururlar. Dallanmış bileşikler daha kolay jel oluşturur ve zincir uzunluğunca herhangi bir etkileşim mümkün olmadığından daha kararlı bir yap1 gösterirler (Glaue, 2018).

Ancak bir bitkinin eksüdası ya da ekstratının gam $\mathrm{m} 1$ yoksa müsilaj $\mathrm{m} 1$ olarak adlandırılması gerektiğine dair tatmin edici bir çözüm olmamakla birlikte sözlük anlamı olarak da yetersizdir. Tohum ekstraktının kabuk ya da yumuşak 
saplardan akan maddelerin müsilaj olarak adlandırılması yönünde bir eğilim olmakla birlikte, bamya (Hibiscus esculentus), psyllium (Plantago spp.; Plantaginaceae, Scrophulariales), keten tohumu (Linum usitatissimum; Linaceae, Geraniales) ve ruredzo (Dicerocaryum zanquebarium) müsilajlara örnek olarak gösterilmektedir (Mohammadifar vd. 2006).

\section{Bitki Tohumlarından Müsilaj Ekstraktsiyonu} Bitki tohum musilajları (BTM) yüksek hidrofilik yapıları nedeniyle bozulmamıs tohum ve tohum kabuklarının suyla muamele edilmesi ile ekstrate edilebilir. Tohumun orjini ve genotipi, ekstraksiyonda kullanılacak çözücünün $\mathrm{pH}$ ve sıcaklığı, ekstraksiyon süresi, tohum ve çözücü oranı gibi etkenlere bağlı olarak ekstraksiyon randımanı $\% 3$ ile $\% 35$ arasında değişebilmektedir. Ancak bazı durumlarda tohumların suya sslanması musilajin yeteri kadar çözünmesini sağlamaz. Hafif çalkalama işlemi yapişkan olmayan dış musilaj tabakasinın ektraksiyonunu arttırsa da içteki yapışkan tabakanın çözünmesi sadece hedeflenen fiziksel, kimyasal ya da enzimatik muamele yoluyla sağlanabilir (Soukulis vd. 2018).

BTM ekstraksiyonunda klasik yöntemin dışında ultrases, mikrodalga gibi yöntemlerin de kullanıldığ1 bilinmektedir. Nazir vd. (2017), fesleğen tohumlanndan musilaj ekstraksiyonunun optimizasyonunu gerçekleştirdikleri çalışmada sıcaklık ve ekstraksiyon süresinin artmasıyla musilaj ekstraksiyonunun arttığ ancak $80{ }^{\circ} \mathrm{C}$ ve üzeri sicakliklarda polisakkarit degredasyonuyla birlikte ekstraksiyon veriminin düştüğü ifade edilmiştir. Sabit sıcaklık ve süre koşullarında su/tohum oranı artışının ise verimi artırdığı, ekstraksiyon süresi ile su/tohum oranı artışının da ektraksiyon verimini artırdığı gözlemlenmiştir. Artan su/tohum oranı ile suyun daha iyi itici güç olduğu ve sıcaklık artışının ise suyun tohum içerisine penetrasyonunun kolaylaşması sonucu verimi arttırdığı ifade edilmiştir.

Klasik ekstraksiyon yöntemine alternatif olarak kullanılan mikrodalga yönteminde ise mikrodalga gücü ve ektraksiyon süresinin artmasiyla musilaj veriminin arttı̆̆ı, işlem sırasında gerçekleşen sıcaklık artışının musilajın çözünmesini kolaylaştırarak ektraksiyon verimini olumlu etkilediği belirtilmiştir (Haddache vd. 2016; LuHan vd. 2016). Ultrases yöntemi ile gerçekleştirilen ektraksiyonlarda ultrases şiddeti ve ekstraksiyon süresinin musilaj ekstraksiyon verimini artırdığ1 ancak ultrases ile oluşan kavitasyon köpüklerinin termomekanik etkisinden dolayı polisakkaritlerin yapısını değiştirdiği gözlemlenmiştir. Ekstraksiyon süresinin artmasiyla bu degredasyonun daha belirgin görüldüğü ifade edilmiştir (Fabre ve Pereira, 2015).

Tohum musilajlarının ekstraksiyonunda ayrıca enzim destekli ekstraksiyon, presleme gibi yardımcı işlemler ile ilgili çalışmalar da gerçekleştirilmiştir (Chiang vd. 2019; Gheribi vd. 2019; Da Silva vd. 2019).

\section{Tohum Musilajlarının Teknolojik Özellikleri ve Gıda Uygulamaları}

Müsilajlar, hidrofobik ya da hidrojen bağı yoluyla polimer zincir yan gruplarının moleküller arası interaksiyonu sebebiyle kalınlaştırıcı ve yapı oluşturucu olarak kullanilırlar. Polimer zincirlerinin akış yönüne uyum sağlama yetenekleri müsilaj solüsyonlarına psödoplastik özellik kazandirır. Keten tohumu ve sarı hardal gibi bitkilerde bulunan iyonik yapıdaki müsilajlar iyonik şiddet ve $\mathrm{pH}$ değişimlerine karşı daha duyarlıdır. Diğer taraftan tere ve çiya tohumundaki gibi ksantan gam iyonik özellik göstermeyen ticari gamlara benzemekte ve $\mathrm{pH}$ değişimlerine duyarlllık göstermemektedir (Soukoulis vd. 2018).

Hidrojen katyonlarının artşsı, aynı yüklü yan zincir grupları arasındaki itme kuvvetini azaltarak polimer zincirlerinin hidrojen bağlanması ile birleşme bölgelerinin oluşumuna neden olur ve böylece keten tohumu ve sarı hardal gamları ve bunlarnn pektik olmayan fraksiyonları asit jel oluşturabilitler (Qian vd. 2012; Chen vd. 2006; Wu vd. 2009). Düşük konsantrasyonlarda katyonların $\left(\mathrm{K}^{+}, \mathrm{Na}^{+}, \mathrm{Ca}^{2+}\right)$ varlığı, BTM sulu sistemlerinde jel dayanımını artırır. Fakat katyonların yüksek konsantrasyonlarda olması polimer molekülleri arasındaki elektrostatik itme kuvvetlerinden dolayı jel dayanımını azaltır (Chen 
vd. 2006). İyonik jellerin mekanik özellikleri musilaj konsantrasyonuna ve üronik asit içeriğine bağlı olarak değissmektedir. Düşük üronik asit içeriğine sahip tohum müsilajlarının katyonların varllğında viskozimetrik tepkisi olumsuz etkilenmektedir (Soukoulis vd. 2018).

BTM' lerin yapıyı modifiye etmelerindeki en önemli parametrelerden biri de şekerdir. BTM dispersiyonlarında şekerin de yer alması reolojik parametreler üzerinde önemli bir etkiye sahiptir. Şekerle birlikte çözünen maddelerin yeterli miktarda mevcut olduğu durumlarda BTM' lerin yapı uyumunu değiştirerek etki eder. Bazı durumlarda ise bu maddelerin düşük konsantrasyonlarda olumsuz bir etki gösterdiği belirtilmiştir (Behrouzian vd. 2013; Capitani vd. 2016).

Protein safsızlıklarının varlı̆ı BTM' lerin viskozimetrik ve reolojik özelliklerini etkilemektedir. Protein safsızliklarının uzaklaştırılması BTM' lerin kalınlaştırıcı ve jel oluşturma kapasitelerini önemli ölçüde geliştirmektedir. Safsızlıkların giderilmesi musilaj çözünürlüğünü arttırır, yan zincir gruplarının yapisal olarak engellenen moleküller arası etkileşimini ortadan kaldırır ve daha yüksek viskozimetrik etkilere ve mekanik deformasyonu sürdüren düzenli biyopolimer ağlarını oluşturulmasına yol açar (Razmkhah vd. 2016a; Razmkhah vd. 2016b).

Polimerlerdeki hidrofobik ve hidrofilik yan zincir gruplarının varlı̆̆ yüzey aktif özellik kazandırmaktadır. Bu yüzden hidrokolloidler güçlü yüzey aktif maddeler olarak kabul edilmezler (Tabasi vd. 2017).

Molekül ağırlığı, protein oranı, zincir esnekliği ve üronik asit varllğı BTM arayüzey aktivitesini etkileyen önemli parametrelerdir (Tabasi vd. 2017). Müsilajların düşük konsantrasyonlarda stabilize etme etkisi ise amfilik karakteri ile ilişkilidir ve protein safsızlıklarının varlığ1 yağ-su arayüzeyinde adsorpsiyonu arttrir. Bazı çalışmalar, protein parçalarının elimine edilmesinin yüzey geriliminde önemli düzeyde artışa sebep olarak yüzey aktif olmayan gamlara kıyasla daha düşük emülsifiye edici kapasiteye yol açtı̆̆ını göstermiştir (Soukoulis, 2017).

Bitki tohumlanndan ve bitkinin diğer bölümlerinden elde edilen musilajlar şeker ve üronik asit birimlerinden oluşan kompleks polisakkaritler olup endüstride ise kalınlaşturıcı, emilsülfiye edici, jelleştirici, bağlayıcı gibi amaçlarla kullanılmaktadır. Bununla birlikte eczacilık alanında geniş çapta kullanılmakta olup medikal kullanımının da olduğu bilinmektedir (Hassan vd. 2015). Son zamanlarda BTM'lerin ticari hidrokolloidlerle sinerjistik etkisinden yararlanilarak gida endüstrisindeki uygulamalarında artış meydana gelmiştir (Staffolo vd. 2017).

Tere musilaj1 kullanılarak üretilen yoğurtta, depolama boyunca fermentasyon süresinde, $\mathrm{pH}$ değerinde ve proteoliz enzimleri üzerinde önemli ölçüde değişiklik olmadı̆̆ saptanmıştr. Yoğurt kalite parametreleri ile pozitif bir ilişki gösteren tere musilaj1 serum proteinlerinin ayrılmasını azaltmış ve yoğurt vizkozitesini arttırmıştır. Bununla birlikte depolama süresine bağlı olarak uçucu bileşenlerde(asetaldehit ve diasetil) düşüş görülmüştür (Hassan vd. 2015).

Fesleğen tohumu musilajı karboksimetilselüloz ve guar gam gibi ticari hidrokolloidlere k1yasla dondurma örneklerinde rekristalizasyonu azaltmış ve kristal büyüklüğünü önemli ölçüde etkilememiştir. Fesleğen tohumu musilajı kristal büyüme hızını \%30-40 arasında azaltmış ve partikül büyüklügünü arttırmıştır (BahramParvar vd. 2013). Fesleğen tohum gamı düşük yağ içerikli dondurmalarda istenilen reolojik özellikleri kazandırmıştır. Bununla beraber erime hızı düşerken yağ ikamesi kullanılan örneklerde erime süresi ve ilk damlama sürelerinde artış görülmüştür (Javidi vd. 2016). BTM önemli ölçüde arayüzey aktivitesi gösterebilmekte olup sütte yağ-su ve hava-su arayüzeylerini stabilize etmektedir. Ayrıca çiya ve fesleğen musilajlarının serum viskozitesini artturarak dondurmada stabilizasyonu sağladığı belirtilmiştir (Yadav vd. 2016).

Arzu edilen tekstürü oluşturmaları ve raf ömrünü uzatmaları sebebiyle hidrokolloidlerin firncilık 
ürünlerinde kullanımları da karşımıza çıkmaktadır (Kohajdova vd. 2009). Glutensiz ürünler gibi yeniden formüle edilen ürünlerde yapiy1 iyileştirmek ve bayatlamayı geciktirmek amacıyla kullanılmaktadır (Smith vd. 2004). Musilajların hidrojel oluşturma yeteneği pişirme esnasinda ürün içerisinden kabuk kısmına doğru su buharı geçişini kontrol etmekte ve bu sayede son üründeki ağırlık ve hacim kaybı en aza indirilmektedir (Fernandes vd. 2017). Keklerde shortening ve yumurta yerine $\% 25$ ve $\% 75$ oranında kullanılan çiya tohumu hidrojeli doymuş yağ, kolesterol ve kalori alımının önemli ölçüde azalmasını sağlamıştır. Ayrıca keklerin spesifik hacmi, nem içeriği ve yapısal özelliklerinin korunmasını sağlamasına rağmen musilaj kullanımı organoleptik özellikleri önemli derecede değiştirerek tüketici tercihini olumsuz yönde etkileyeceğinden yağ miktarının azaltıldığ1 formülasyonlarda kismen kullanilabilmektedir (Soukulis vd. 2018). Çiya tohumu ile zenginleştirilen pita ekmeğinde, ekmek içinin glisemik indeksi yüksek miktarda nişasta jelatinizasyonundan dolayı artış göstermiş ve kabuk kısmında düşük jelatinizasyon derecesinden dolayı musilaj ilavesi glisemik indeksin azalmasina sebep olmuştur (SalgadoCruz vd. 2017). Son zamanlarda, glütensiz ürünlere yapı kazandırmak amaciyla hamur ve kabartma geliştirici olarak B'TM kullanımı artış göstermiştir. Korus ve ark. (2015), yaptığ1 bir çalışmada \%1,2 ile 2,4 oranlarında keten tohumu müsilajının, pektin ve guar gam gibi ticari hidrokolloidler ile benzer şekilde glutensiz ekmeğin duyusal kalitesini arttırmak ve hamurun viskoelastik, fiziksel ve mekaniksel özelliklerini korumak için kullanılabileceği ifade edilmiştir. Guar gam ve pektinin yerine keten tohumu müsilajının kullanılması ekmeğin duyusal olarak kalitesini arttırmış, tekstür ve bayatlama üzerinde ise sınırlı etki göstermiştir. Ayrıca, keten tohumu ilavesi nişasta retrogradasyonuna bağlı olarak ekmeğin termo fiziksel yapısını değiştirmemiştir. Glutensiz makarnaya çiya tohum müsilajı ilavesi ile son ürünün pişirme kalitesinde gelişme görülmemiş makarnanın çözünen çözünmeyen lif, fenolik bileşikler ve protein içeriğinin artması ile besinsel profilinde iyileşme gerçekleşmiştir (Menga, 2017). Çiya tohumu ilavesi ile üretilen galetaların kimyasal ve fiziksel bazı özelliklerinin araştırıldığı bir çalışmada, çiya tohumu ilavesinin toplam ağırlık kaybına etkisi gözlenmezken çiya tohumunun oranı arttıkça ağılık kaybında nispeten de olsa artış olduğu görülmüştür (Özgören, 2018). Çiya müsilaj1 ile hazırlanan ekmek ve çikolatalı kekte, müsilajlar farklı oranlarda yağ ikame edicisi olarak kullanılmış ve $\% 50$ oranında yağ ikamesi olarak kullanilan örneklerde ürünün fiziksel ve teknolojik özelliklerinde bir değişiklik gözlenmemiştir. Bu durum çiya müsilajının gıda endüstrisinde yağ ikamesi alternatifi olarak kullanılabileceği şeklinde ifade edilmiştir. Bununla birlikte kek üretiminde $\% 75$ ve üzeri oranlarda kullanılan müsilaj kek hacmini azaltmıştur (Fernandes vd. 2017). Püskürtülerek kurutulmuş probiyotik bakteriler (L. acidophilus, L. plantarum and B. infantis) içeren maltodekstrin/protein tozuna, keten ya da çiya müsilajlarının katılması hücrelerin biyolojik aktivitelerini dehidrasyon boyunca korumuştur (Soukulis vd. 2018). Psyllium müsilajının L. plantarum hücresini immobilize etme potansiyeli, patates nişastası ve inülinle kıyaslandığında sert gastrointestinal sivilara maruz kalma sonucu ortaya çıkan hücre zararını etkili biçimde engellediği görülmüştür. Çözücü ile yer değiştirme metodu ile oluşturulan çiya müsilaj1 nanopartikülleri yağ enkapsülasyonunda kullanılmış olup nanopartiküller lipit damlacıklarının instabilitesini arttırmıs ve mono ve poli-doymamış yă asitlerinin oksidatif bozunmasına karşı somut bir fiziksel bariyer sağlamıştr (Peredo vd. 2016). Çiya tohumu yağının çiya musilajı ile enkapsülasyonu sonucunda, depolama süresince fiziksel ve termal stabilite korunmuştur. Hızlandırılmış koşullardaki 28 günlük depolama süresince yağın oksidatif stabilitesinin korunması çiya musilajının biyoaktif yağların enkapsülasyonunda başarıyla kullanılabileceğini göstermiştir (de Campo vd. 2017). BTM birçok yağ/su ya da su/yağ emülsyonunda stabilizasyon sağlamak, yap1 oluşturmak ya da tekstür sağlamak için kullanılmaktadır. Çiya müsilajı sürekli su fazında disperse olan miktarına bağlı olarak yağ/su emilsiyonlarını stabilize edici etki göstermiştir. Yağ damlacıklarının boyutunda meydana gelen artışa rağmen musilaj konsantrasyonunun artması, 
damlacıkların biraraya gelmesini ve yerçekimsel ayrılmayı inhibe etmiştir (Capitani vd. 2016). Çiya müsilajının yă̆-su arayüzeyini stabilize etme yeteneğinin çiya müsilajının kompozisyonel ve mikroyapısal çeşitliliğine katkı sağlayan, yağ su ara yüzeyinin çevresinde heterojenus viskoelastik yapıların oluşumuyla ilişkili olduğu düşünülmektedir (Avila-de la Rosa, 2015). Tek başına ya da jelatin ile karışım halinde fesleğen tohum müsilajının protein miyofibriler jelinin pişirme kalitesi ve viskoelastik özelliklerini üzerine etkisi araştırlmıştır. Musilaj ile jelatin arasındaki sinerjistik etkinin pişirme randımanını, jel gücünü ve yap1 yoğunluğunu arttırdığı saptanmıştır. Ayrıca, su salınımını azalttığı görülmüş olup protein-jelatin-fesleğen gamı interaksiyonuna sebep olan kovalent bağlanmanın budurumun sebebi olduğu düşünülmektedir (Lee vd. 2017). Yüksek miktarda nişasta (\%8-30), gam (\%11-44) ve müsilaj maddesi (\%6-61) içeren sahlep ilavesi ile üretilen sucukların sertlik değerinin arttı̆1 ancak diğer tekstürel parametreler üzerinde herhangi bir etkinin söz konusu olmadığ1 belirtilmiştir (Gök vd. 2018). Çiya tohumunun jelleşme özelliklerinin modifiye pektin türlerine çok yakın olduğu gözlenmiştir. Bu sonuç, ticari reçeller veya soslarda pektin yerine çiya tohumunun kullanılabileceğini göstermektedir. Reolojik parametreler, şekersiz çiya tohumu ilaveli marmelatın kayma incelme özelliği taşıdığını göstermiştir. Çiya tohumu ilavesinin viskoziteyi artırdığ1 tespit edilmiştir (Özbek vd. 2019). Balangu tohum müsilajlarından yenilebilir film üretimi üzerine yapılan bir çalışmada ise; balangu müsilajının sergilediği mekanik, su buharı ve oksijen geçirgenliği özelliklerinin ambalajlama uygulamaları için potansiyel bir aday olduğu gösterilmiştir (Sadeghi-Varkani vd. 2018). Farklı tohum musilajlarının kullanıldığ 1 ürünler ve son ürünlerdeki değişimler Çizelge 1' de verilmiştir.

Çizelge 1. Farklı tohum musilajlarının son ürün özelliklerine etkisi

\begin{tabular}{|c|c|c|c|c|}
\hline Ürün & Musilaj Tipi & $\begin{array}{l}\text { Kullanım } \\
\text { Amaci }\end{array}$ & Sonuç & Kaynak \\
\hline Dondurma & $\begin{array}{l}\text { Çiya tohum } \\
\text { musilajı }\end{array}$ & $\begin{array}{l}\text { Stabilizatör } \\
\text { Köpük } \\
\text { oluşturucu }\end{array}$ & $\begin{array}{l}\text { Erime direncinde artma } \\
\text { Tat, tekstür ve genel kabul edilebilirlik } \\
\text { üzerine olumsuz etki }\end{array}$ & Campos vd. (2016) \\
\hline $\begin{array}{l}\text { Portakal } \\
\text { suyu }\end{array}$ & $\begin{array}{l}\text { Çiya tohum } \\
\text { musilaj1 }\end{array}$ & $\begin{array}{l}\text { Kaplama } \\
\text { materyali }\end{array}$ & $\begin{array}{l}\text { Yülksek L ve düşük a* değeri } \\
\text { Uygun biyoerişilebilirlik düzeyi }\end{array}$ & Stefani vd. (2019) \\
\hline $\begin{array}{l}\text { Bologna } \\
\text { sosisi }\end{array}$ & $\begin{array}{l}\text { Çiya tohum } \\
\text { musilaj1 }\end{array}$ & Yağ ikamesi & Benzer iştah ve tokluk hissi & Camara vd. (2020) \\
\hline $\begin{array}{l}\text { Yenilebilir } \\
\text { film }\end{array}$ & $\begin{array}{l}\text { Çiya tohum } \\
\text { musilajı }\end{array}$ & $\begin{array}{l}\text { Film } \\
\text { oluşturucu }\end{array}$ & $\begin{array}{l}\text { Yüksek su çözünürlüğü, termal direnç, } \\
\text { şeffaflık } \\
\text { Plastikleştirici içeriğine bağlı olarak } \\
\text { kabul edilebilir gerilme kuvveti, esneklik } \\
\text { ve uzayabilirlik }\end{array}$ & Dick vd. (2015) \\
\hline Pound kek & $\begin{array}{l}\text { Çiya tohum } \\
\text { musilaj1 }\end{array}$ & Yağ ikamesi & $\begin{array}{l}\text { Spesifik hacim ve ekmek içi sertliğinde } \\
\text { artma } \\
\text { Ekmek içi L* değerinde azalma }\end{array}$ & $\begin{array}{l}\text { Felisberto } \\
(2015)\end{array}$ \\
\hline Sütlü tatlı & $\begin{array}{l}\text { Ayva tohum } \\
\text { musilaj1 }\end{array}$ & $\begin{array}{l}\text { Kaplama } \\
\text { materyali }\end{array}$ & $\begin{array}{l}\text { L. rhamnosus için bağırsak-mide } \\
\text { koşullarında artan dayanıklılık } \\
\text { Sertlik, çiğnenebilirlik, yapışkanlık } \\
\text { değerlerinde artış }\end{array}$ & $\begin{array}{l}\text { Dokoohaki vd. } \\
(2019)\end{array}$ \\
\hline $\begin{array}{l}\text { Yenilebilir } \\
\text { film }\end{array}$ & $\begin{array}{l}\text { Ayva tohum } \\
\text { musilaj1 }\end{array}$ & $\begin{array}{l}\text { Film } \\
\text { oluşturucu }\end{array}$ & $\begin{array}{l}\text { Iyi antioksidan ve antibakteriyel } \\
\text { kapasite } \\
\text { Kabul edilebilir mekanik ve bariyer } \\
\text { Özellikler }\end{array}$ & Jouki vd. (2013) \\
\hline Yoğurt & $\begin{array}{l}\text { Keten tohumu } \\
\text { musilaji }\end{array}$ & Stabilizatör & $\begin{array}{l}\text { Azalan yapışkanlık } \\
\text { Gelişmiş tekstür, azalan su salınımı } \\
\text { Düşük genel kabul edilebilirlik }\end{array}$ & Basiri vd. (2018) \\
\hline Noodle & $\begin{array}{l}\text { Keten tohumu } \\
\text { musilaj1 }\end{array}$ & $\begin{array}{l}\text { Fonksiyonel } \\
\text { bileşik }\end{array}$ & $\begin{array}{l}\text { Pişme kaybında artma } \\
\text { Sertlik ve çekme direncinde azalma }\end{array}$ & Zhu ve Li (2019) \\
\hline
\end{tabular}




\section{SONUÇ}

Bitki kökenli hidrokolloidler hayvansal hidrokolloidlere alternatif olarak ortaya çımış ve son zamanlarda bu konudaki araştırmalar artmıştır. Musilajların kalınlaştırma, jel oluşturma ve emülsifiye etme gibi yapı üzerinde teknolojik etkileri olup diyet lifi olması açısından da fonksiyonel özellik göstermektedir. Musilaj ekstraksiyon koşulları, bahsedilen özellikler üzerinde önemli bir faktördür. Musilajların gıda uygulamaları ile ilgili çalışmalar hız kazanmakta olup mevcut ticari hidrokolloidler ile rekabet edebilecek düzeyde olumlu etkiler gösterebilmektedir. Ancak yapıdaki protein grupları gibi bazı safsızlıklar teknolojik özellikleri olumsuz şekilde etkileyebilmektedir. Musilajların ekstraksiyon sonrası saflaştırılmaları ile ilgili çalışmaların gerçekleştirilmesinin bu noktadaki problemleri çözeceği düşünülmektedir.

\section{ÇIKAR ÇATIŞMASI BEYANI}

Yazarların, başka kişiler ve/veya kurumlar ile çıar çatışması bulunmamaktadır.

\section{YAZAR KATKILARI}

Tüm yazarlar makalenin kaynak tarama, yazma, düzenleme aşamalarında katkıda bulunmuşlardır. Yazarlar makalenin son halini okumuş ve onaylamıstır.

\section{KAYNAKLAR}

Abdurrahmanoğlu, E. T. (2017). Yetişkinlerde Tam Tahıl Yeme İsteği, Diyet Lifi Bilgi Düzeyi ve Tam Tahıl Tüketimi İle Depresyon Arasındaki İlişkinin Değerlendirilmesi, Acıbadem Üniversitesi Sağlık Bilimleri Enstitüsü Beslenme ve Diyetetik Anabilim Dalı Yüksek Lisans Tezi, İstanbul, Türkiye, $150 \mathrm{~s}$.

Avila-de la Rosa, G., Alvarez-Ramirez, J., Vernon-Carter, E.J., Carrillo-Navas, H., PérezAlonso, C. (2015). Viscoelasticity of chia (Salvia hispanica L.) seed mucilage dispersion inthe vicinity of an oil-water interface. Food Hydrocoll, 49: 200-207, https://doi.org/10.1016/j.foodhyd. 2015.03.017.

BahramParvar, M., Tehrani, M.M., Razavi, S.M.A. (2013). Effects of a novel stabilizer blend and presence of $x$-carrageenan on some properties of vanilla ice cream during storage. Food Biosci, 3: 1018, https://doi.org/10.1016/j.fbio.2013.05.001.

Basiri, S., Haidary, N., Shekarforoush, S.S., Niakousari, M. (2018). Flaxseed mucilage: A natural stabilizer in stirred yogurt. Carbohydr Polym, 187: 59-65, https://doi.org/10.1016/j.carbpol. 2018.01.049.

Behrouzian, F., Razavi, S.M.A., Karazhiyan, H. (2013). The effect of $\mathrm{pH}$, salts and sugars on the rheological properties of cress seed (Lepidium sativum) gum. Int J Food Scl Tech, 48(12): 25062513, https://doi.org/10.1111/ijfs.12242.

Bemiller, J.N. (2011). Pasting, paste, and gel properties of starch-hydrocolloid combinations. Carbobydr Polym, 86(2): 386-423, https://doi.org/10.1016/j.carbpol.2011.05.064.

Câmara, A.K.F.I., Geraldi, M.V., Okuro, P.K., Maróstica, M.R., Da Cunha, R.L., Pollonio, M.A.R. (2020). Satiety and in vitro digestibility of low saturated fat Bologna sausages added of chia mucilage powder and chia mucilage-based emulsion gel. J Funct Foods, 65: 103753, https://doi.org/10.1016/j.jff.2019.103753.

Campos, B.E., Dias Ruivo, T., Da Silva Scapim, M.R., Madrona, G.S., De C. Bergamasco, R. (2016). Optimization of the mucilage extraction process from chia seeds and application in ice cream as a stabilizer and emulsifier. Lwt-Food $S_{c l}$ Technol, 65: 874-883, https://doi.org/10.1016/ j.lwt.2015.09.021.

Capitani, M.I., Nolasco, S.M., Tomás, M.C. (2016). Stability of oil-in-water (O/W) emulsions with chia (Salvia hispanica L.) mucilage. Food Hydrocoll, 61: 537-546. https://doi.org/10.1016/ j.foodhyd.2016.06.008.

Chen, H.H., Xu, S.Y., Wang, Z. (2006). Gelation properties of flaxseed gum. J. Food Eng, 77(2): 295-303, https://doi.org/10.1016/j.jfoodeng. 2005.06.033.

Chiang, C. F., Lai, L. S. (2019). Effect of enzymeassisted extraction on the physicochemical properties of mucilage from the fronds of Asplenium australasicum (J. Sm.) Hook. Int J Biol Macromol, 124: 346-353, https://doi.org/ 10.1016/j.ijbiomac.2018.11.181. 
Da Silva Stefani, F., De Campo, C., Paese, K., Stanisçuaski Guterres, S., Haas Costa, T.M., Hickmann Flôres, S. (2019). Nanoencapsulation of linseed oil with chia mucilage as structuring material: Characterization, stability and enrichment of orange juice. Food Res Int, 120: 872879, https://doi.org/10.1016/j.foodres.2018.11.052.

De Campo, C., Dos Santos, P.P., Costa, T.M.H., Paese, K., Guterres, S.S., Rios, A. De O., Flôres, S.H. (2017). Nanoencapsulation of chia seed oil with chia mucilage (Salvia hispanica L.) as wall material: Characterization and stability evaluation. Food Chem, 234: 1-9, https://doi.org/ 10.1016/j.foodchem.2017.04.153.

Dello Staffolo, M., Sato, A.C.K., Cunha, R.L. (2017). Utilization of Plant Dietary Fibers to Reinforce Low-Calorie Dairy Dessert Structure. Food Bioproc Tech, 10(5): 914-925, https://doi.org/10.1007/s11947-017-1872-9.

Dick, M., Costa, T.M.H., Gomaa, A., Subirade, M., Rios, A.D.O., Flôres, S.H. (2015). Edible film production from chia seed mucilage: Effect of glycerol concentration on its physicochemical and mechanical properties. Carbohydr Polym, 130: 198205, https://doi.org/10.1016/j.carbpol. 2015.05.040.

Dokoohaki, Z.N., Sekhavatizadeh, S.S., Hosseinzadeh, S. (2019). Dairy dessert containing microencapsulated Lactobacillus rhamnosus (ATCC 53103) with quince seed mucilage as a coating material. Lwt, 115: 108429, https://doi.org/10.1016/j.lwt.2019.108429.

Fabre, J.F., Lacroux, E., Gravé, G., Mouloungui, Z. (2020). Extraction of camelina mucilage with ultrasound and high flow rate fluid circulation. Ind Crop Prod, 144: 112057, https://doi.org/10.1016/ j.indcrop.2019.112057.

Felisberto, M.H.F., Wahanik, A.L., Gomes-Ruffi, C.R., Clerici, M.T.P.S., Chang, Y.K., Steel, C.J. (2015). Use of chia (Salvia hispanica L.) mucilage gel to reduce fat in pound cakes. Lwt-Food Sci Technol, 63(2): 1049-1055.

Felkai-Haddache, L., Dahmoune, F., Remini, H., Lefsih, K., Mouni, L., Madani, K. (2016). Microwave optimization of mucilage extraction from Opuntia ficus indica Cladodes. Int $J$ Biol Macromol, 84: 24-30, https://doi.org/10.1016/ j.ijbiomac.2015.11.090.

Fernandes, S.S., Salas-Mellado, M. De Las M. (2017). Addition of chia seed mucilage for reduction of fat content in bread and cakes. Food Chem, 227: 237-244, https://doi.org/10.1016/ j.foodchem.2017.01.075.

Gheribi, R., Gharbi, M.A., El Ouni, M., Khwaldia, K. (2019). Enhancement of the physical, mechanical and thermal properties of cactus mucilage films by blending with polyvinyl alcohol. Food Packag Shelf Life, 22: 100386 , https://doi.org/10.1016/j.fpsl.2019.100386.

Gök, İ., Kılıç, B., Özer, C.O. (2018). Salep Kullanımının Fermente Türk Sucuğu Kalite Parametreleri. Türk tarm gida bilim teknol derg, 6(2): 219-225, https://doi.org/10.24925/turjaf.v6i2. 219-225.1593.

Han, Y.L., Gao, J., Yin, Y.Y., Jin, Z.Y., Xu, X.M., Chen, H.Q. (2016). Extraction optimization by response surface methodology of mucilage polysaccharide from the peel of Opuntia dillenii haw. fruits and their physicochemical properties. Carbobydr Poly, 151: 381-391, https://doi.org/10.1016/j.carbpol.2016.05.085.

Hassan, L.K., Haggag, H.F., ElKalyoubi, M.H., Abd EL-Aziz, M., El-Sayed, M.M., Sayed, A. F. (2015). Physico-chemical properties of yoghurt containing cress seed mucilage or guar gum. Ann Agric Sci, 60(1): 21-28, https://doi.org/ 10.1016/j.aoas.2014.11.021.

Hung, P.Y., Lai, L.S. (2019). Structural characterization and rheological properties of the water extracted mucilage of Basella alba and the starch/aqueous mucilage blends. Food Hydrocoll, 93, 413-421, https://doi.org/10.1016/j.foodhyd. 2019.02.037.

Jani, G.K., Shah, D.P., Prajapati, V.D., Jain, V.C. (2009). Gums and mucilages: versatile excipients for pharmaceutical formulations. Asian J Pharm Sci, 4(5): 308-322.

Javidi, F., Razavi, S.M.A., Behrouzian, F., Alghooneh, A. (2016). The influence of basil seed gum, guar gum and their blend on the rheological, 
physical and sensory properties of low fat ice cream. Food Hydrocoll, 52: 625-633, https://doi.org/10.1016/j.foodhyd.2015.08.006.

Jouki, M., Tabatabaei Yazdi, F., Mortazavi, S.A., Koocheki, A. (2013). Physical, barrier and antioxidant properties of a novel plasticized edible film from quince seed mucilage. Int J Biol Macromol, 62: 500-507, https://doi.org/10.1016/ j.ijbiomac.2013.09.031.

Kohajdová, Z., Karovičová, J. (2009). Application of hydrocolloids as baking improvers. Chem Pap, 63(1): 26-38, https://doi.org/10.2478/s11696008-0085-0.

Korus, J., Witczak, T., Ziobro, R., Juszczak, L. (2015). Linseed (Linum usitatissimum L.) mucilage as a novel structure forming agent in gluten-free bread. Lwt-Food Sci Technol, 62(1): 257264, https://doi.org/10.1016/j.lwt.2015.01.040.

Lee, C. H., Chin, K.B. (2017). Development of low-fat sausages using basil seed gum (Ocimum bacilicum L.) and gelatin as a fat replacer. Int J Food $\quad S_{c l}$ Tech, 52(3): 733-740, https://doi.org/10.1111/ijfs.13328.

Menga, V., Amato, M., Phillips, T.D., Angelino, D., Morreale, F., Fares, C. (2017). Gluten-free pasta incorporating chia (Salvia hispanica L.) as thickening agent: An approach to naturally improve the nutritional profile and the in vitro carbohydrate digestibility. Food Chem, 221: 19541961, https://doi.org/10.1016/j.foodchem. 2016.11.151.

Mohammadifar, M.A., Musavi, S.M., Kiumarsi, A., Williams, P.A. (2006). Solution properties of targacanthin (water-soluble part of gum tragacanth exudate from Astragalus gossypinus). Int J Biol Macromol, 38(1): 31-39, https://doi.org/10.1016/j.ijbiomac.2005.12.015.

Naji-Tabasi, S., Razavi, S.M.A. (2017). Functional properties and applications of basil seed gum: An overview. Food Hydrocoll, 73: 313-325, https://doi.org/10.1016/j.foodhyd.2017.07.007.

Nazir, S., Wani, I.A., Masoodi, F.A. (2017). Extraction optimization of mucilage from Basil (Ocimum basilicum L.) seeds using response surface methodology. J Adv Res, 8(3): 235-244, https://doi.org/10.1016/j.jare.2017.01.003.

Öncü Glaue, Ş. (2018). Bamya Müsilajının Termoreolojik Özelliklerinin Belirlenmesi, Ege Üniversitesi Fen Bilimleri Enstitüsü G1da Mühendisliği Anabilim Dalı Doktora Tezi, İzmir, Türkiye, $137 \mathrm{~s}$.

Özbek, T., Sahin-Yesilcubuk, N., Demirel, B. (2019). Quality and Nutritional Value of Functional Strawberry Marmalade Enriched with Chia Seed (Salvia hispanica L.). J Food Qual, 2019: https://doi.org/10.1155/2019/2391931.

Özgören, E., Kaplan, H.B., Tüfekçi, S. (2018). Some Chemical and Physical Properties of Breadsticks Produced By Using Chia Seed. Food and Health, 4(2): 140-146, https://doi.org/ $10.3153 /$ fh1 8014 .

Peredo, A.G., Beristain, C.I., Pascual, L.A., Azuara, E., Jimenez, M. (2016). The effect of prebiotics on the viability of encapsulated probiotic bacteria. Lwt-Food Sci Technol, 73: 191-196, https://doi.org/10.1016/j.lwt. 2016.06.021.

Pereira, G.A., Silva, E.K., Peixoto Araujo, N.M., Arruda, H.S., Meireles, M.A.A., Pastore, G.M. (2019). Obtaining a novel mucilage from mutamba seeds exploring different high-intensity ultrasound process conditions. Ultrason Sonochem, 55: 332-340, https://doi.org/10.1016/ j.ultsonch.2019.01.010.

Qian, K.Y., Cui, S.W., Wu, Y., Goff, H.D. (2012). Flaxseed gum from flaxseed hulls: Extraction, fractionation, and characterization. Food Hydrocoll, 28(2): 275-283, https://doi.org/10.1016/ j.foodhyd.2011.12.019.

Razmkhah, S., Razavi, S.M.A., Mohammadifar, M.A., Ale, M.T., Gavlighi, H.A. (2016a). Proteinfree cress seed (Lepidium sativum) gum: Physicochemical characterization and rheological properties. Carbohydr Polym, 153: 14-24, https://doi.org/10.1016/j.carbpol.2016.07.086.

Razmkhah, S., Razavi, S.M.A., Mohammadifar, M.A. (2016b). Purification of cress seed (Lepidium sativum) gum: A comprehensive rheological study. Food Hydrocoll, 61: 358- 
368, https://doi.org/10.1016/j.foodhyd. 2016.05.035.

Sadeghi-Varkani, A., Emam-Djomeh, Z., Askari, G. (2018). Physicochemical and microstructural properties of a novel edible film synthesized from Balangu seed mucilage. Int J Bio Macromol, 108: 1110-1119, https://doi.org/10.1016/j.ijbiomac. 2017.11.029.

Saha, D., Bhattacharya, S. (2010). Hydrocolloids as thickening and gelling agents in food: A critical review. Int J Food Sci Nutr, 47(6): 587-597, https://doi.org/10.1007/s13197-010-0162-6.

Salgado-Cruz, M. De La P., Ramírez-Miranda, M., Díaz-Ramírez, M., Alamilla-Beltran, L., CalderónDomínguez, G. (2017). Microstructural characterisation and glycemic index evaluation of pita bread enriched with chia mucilage. Food Hydrocoll, 69: 141-149, https://doi.org/10.1016/ j.foodhyd. 2017.01.027.

Silva, S.H., Neves, I.C.O., Oliveira, N.L., De Oliveira, A.C.F., Lago, A.M.T., De Oliveira Giarola, T.M., De Resende, J.V. (2019). Extraction processes and characterization of the mucilage obtained from green fruits of Pereskia aculeata Miller. Ind Crop Prod, 140: 111716, https://doi.org/10.1016/j.indcrop.2019.111716.

Smith, J.P., Daifas, D.P., El-Khoury, W., Koukoutsis, J., El-Khoury, A. (2004). Shelf Life and Safety Concerns of Bakery Products - A Review. Crit Rev Food Sci Nutr, 44(1): 19-55, https://doi.org/10.1080/10408690490263774.
Soukoulis, C., Gaiani, C., Hoffmann, L. (2018). Plant seed mucilage as emerging biopolymer in food industry applications. Curr Opin Food Sci, 22: $28-42$, https://doi.org/10.1016/j.cofs. 2018.01.004.

Wu, Y., Cui, W., Eskin, N.A.M., Goff, H.D. (2009). Fractionation and partial characterization of non-pectic polysaccharides from yellow mustard mucilage. Food Hydrocoll, 23(6): 15351541, https://doi.org/10.1016/j.foodhyd. 2008.10.010.

Yadav, N., Sharma, V., Kapila, S., Malik, R.K., Arora, S. (2016). Hypocholesterolaemic and prebiotic effect of partially hydrolysed psyllium husk supplemented yoghurt. J Funct Foods, 24: 351-358, $\quad$ https://doi.org/10.1016/j.jff. 2016.04.028.

Yu, L., Yakubov, G.E., Zeng, W., Xing, X., Stenson, J., Bulone, V., Stokes, J.R. (2017). Multilayer mucilage of Plantago ovata seeds: Rheological differences arise from variations in arabinoxylan side chains. Carbobydr Poly, 165: 132141, https://doi.org/10.1016/j.carbpol. 2017.02.038.

Zhu, F., Li, J. (2019). Physicochemical and sensory properties of fresh noodles fortified with ground linseed (Linum usitatissimum). Lwt, 101: 847-853, https://doi.org/10.1016/j.lwt. 2018.12.003. 